\title{
Aplikasi gaya belajar pada kegiatan belajar mandiri Mahasiswa tahun pertama fakultas kedokteran Universitas muhammadiyah Makassar
}

\section{Learning styles on application to self-study first year students Faculty of medicine University of Muhammadiyah Makassar}

\author{
Ummu Kalzum Malik, ${ }^{1}$ Ova Emilia, ${ }^{2}$ Retno Gandes Rahayu, ${ }^{2}$ Juliani Ibrahim ${ }^{1}$ \\ ${ }^{1}$ Fakultas Kedokteran Universitas Muhammadivah Makassar, \\ ${ }^{2}$ Bagian Pendidikan Kedokteran, Fakultas Kedokteran, Universitas Gadjah Mada.
}

\begin{abstract}
Abstrak
Latar belakang: Pengetahuan akan gaya belajar sangat dibutuhkan oleh mahasiswa. Pada saat belajar mandiri, mahasiswa memiliki kebebasan untuk untuk dapat mengidentifikasi kebutuhan belajarnya yang akan dijabarkan dalam bentuk tujuan belajar, setelah itu menyiapkan rencana belajar, mencari sumber daya yang dibutuhkan dan melaksanakan rencana belajar tersebut serta diakhir dengan evaluasi hasil dan proses belajar. Dalam proses belajar inilah gaya belajar dapat menjadi katalisator untuk pembelajaran yang efektif. Salah satunya adalah gaya belajar Visual, Aural, Read/write, Kinestetik (VARK).

Metode: Penelitian deskriptif dengan pendekatan kuantitatif terhadap mahasiswa tahun pertama FK Unismuh di TA 2013/2014. Tahap pertama dengan menyebarkan kuesioner VARK untuk mendapatkan data gaya belajar mahasiswa. Selanjutnya mahasiswa diberikan buku harian belajar mandiri untuk diisi sesuai apa yang mereka lakukan saat belajar mandiri.
\end{abstract}

Hasil: Berdasarkan analisis data diperoleh gaya belajar unimodalitas mahasiswa yaitu Visual 1.4\%, Aural $29 \%$, Read/write $24.6 \%$, Kinestetik 32\%, dan multimodalitas 13\%. Dari kelompok unimodalitas hanya sebesar $10 \%$ yang mengaplikasikan gaya belajar sesuai karakteristik gaya belajarnya sedangkan dari kelompok multimodalitas sebesar $77.7 \%$.

Simpulan: Gaya belajar yang paling dominan adalah gaya belajar kinestetik dan kelompok multi modalitaslah yang paling banyak mengaplikasikan gaya belajar sesuai dengan karakteristik gaya belajarnya.

Kata kunci. Aplikasi gaya belajar, gaya belajar VARK, belajar mandiri. 


\section{Abstract}

Background: Knowledge of learning styles is needed by the student. At the time of self-learning, students have the freedom to be able to identify learning needs to be spelled out in the form of learning objectives, and then prepare a lesson plan, look for the resources needed to learn and implement the plan as well as the end of the evaluation results and the learning process. In this learning process learning styles can be a catalyst for effective learning. One of which is the Visual, Aural, Read / write, Kinesthetic (VARK).

Methods: Descriptive study with a quantitative approach. The population was freshman FK Unismuh in school year 2013/2014. The data were taken by quetionnaires to obtain data VARK learning styles of students. Then, students are given self-learning diary filled according to what they do when the independent study.

Result: Learning style is Visual 1.4\%, 29\% Aural, Read / write 24.6\%, Kinesthetic 32\%, 13\% and multimodality. Of group unimodalitas only $10 \%$ who apply learning style according to the characteristics of learning styles while multimodality group at $77.7 \%$.

Conclusion: The most dominant learning style is kinesthetic but group multimodality most widely applied according to the learning style characteristics.

Keywords. Application of learning styles, VARK learning style, self-learning.

\section{PENDAHULUAN}

Belajar didefenisikan sebagai proses perubahan perilaku yang relatif permanen sebagai akibat dari pengalaman. ${ }^{1}$ Salah satu faktor yang berperan dalam proses belajar adalah karekteristik mahasiswa. Mahasiswa yang mengetahui cara belajar "knowing how to study" akan sukses dalam proses belajarnya. ${ }^{2} \mathrm{Hal}$ ini sangat penting mengingat dalam pendidikan kedokteran, mahasiswa dihadapkan pada begitu banyak materi atau ilmu pengetahuan yang harus dipelajari, keterampilan-keterampilan yang harus dikuasai dan ujian-ujian yang harus dilalui agar dapat memecahkan masalah kesehatan. ${ }^{3}$

Menurut Heruistic Model of Learning dari Entwistle, gaya belajar (learning style) dan pendekatan belajar (learning approach) dianggap mempengaruhi keberhasilan suatu proses pembelajaran. Gaya belajar dapat menjadi katalisator untuk pembelajaran yang efektif. ${ }^{4}$ Gaya belajar sangat mungkin mencerminkan strategi dan pendekatan belajar yang akan dipergunakan. Pembelajar yang efektif tahu kapan harus menggunakan strategi yang diberikan serta kapan harus meninggalkannya dan mencoba yang lain lagi. ${ }^{5}$

Dunia pendidikan mengakui pentingnya memahami anak didik dengan preferensi gaya belajar yang berbeda-beda dan peran mereka dalam mencapai keberhasilan akademik. Istilah gaya belajar menggambarkan metode preferensi individu dalam mengumpulkan, mengolah, menafsirkan, mengorganisir dan menganalisa informasi. Gaya tidak sama dengan kemampuan. Kemampuan mengacu pada kapasitas untuk belajar dan menggunakan keterampilan sementara gaya adalah cara yang biasa digunakan dalam memproses dan menggunakan informasi. Gaya belajar yang dikembangkan oleh Flemming dan Milis membagi peserta didik dengan profil gaya belajar berdasarkan modalitas sensorik yang terlibat dalam mengambil informasi.

Flemming dan Mills mengemukakan empat modalitas yang tampaknya mencerminkan pengalaman belajar seseorang. ${ }^{6}$ Format kuesioner internet maupun paper test menggunakan 16 pertanyaan yang memungkinkan pengguna mengetahui tipe gaya belajarnya. Kuesioner VARK menguji gaya belajar visual, aural, kinestetik-perseptual, juga menguji mode visual/taktil yang disebut oleh Fleming sebagai mode read/write. Setiap peserta mendapat 4 nilai tipe gaya belajar dengan skala 0-16 dimana skala tersebut menggambarkan dominasi relatif dari visual, aural, read/write dan kinestetik. Setiap kuesioner diberi nilai dan ditabulasikan, apabila masing-masing tipe gaya belajar mempunyai nilai tertinggi yang sama disebut multi modalitas

Belajar tidak akan pernah menjadi beban jika informasi yang harus diperoleh disajikan dalam gaya yang menguntungkan bagi mahasiswa. Jika pembelajaran bisa dibuat 
menyenangkan, kinerja dalam ujian dapat diperbaiki. $^{7}$

Penelitian ini akan melihat aplikasi gaya belajar mahasiswa saat belajar mandiri pada mahasiswa tahun pertama Fakultas Kedokteran Universitas Muhammadiyah Makassar.

\section{METODE PENELITIAN}

Penelitian ini merupakan jenis penelitian deskriptif dengan menggunakan pendekatan kuantitatif dalam analisi datanya. Subyeknya adalah mahasiswa tahun pertama Fakultas Kedokteran Universitas Muhammadiyah tahun ajaran 2013/2014 sebanyak 88 orang. Kriteria inklusi adalah tercatat sebagai mahasiswa aktif disemester satu dibagian akademik untuk tahun ajaran 2013/2014 dan bersedia ikut dalam penelitian. Data pertama diambil dengan menggunakan kuesioner Flemming's VARK learning style yang telah diterjemahkan.

Data kedua diambil menggunakan buku harian belajar mandiri. Buku ini disebarkan kepada semua mahasiswa yang telah mengikuti pengambilan data pertama untuk diisikan sesuai kegiatan belajar mandirinya selama satu minngu. Data buku harian ini kemudian diolah oleh peneliti dengan mengelompokkan kegiatan harian menjadi kegiatan belajar mandiri harian. Kegiatan belajar mandiri inilah yang dicocokkan dengan daftar kegiatan belajar mandiri yang sesuai dengan karakteristik gaya belajar masingmasing mahasiswa. Kegiatan belajar mandiri mahasiswa yang sudah sesuai dengan karakteristik gaya belajarnya diberi tanda centang $(\checkmark)$ dan jika hanya diperoleh 1-2 tanda centang berarti kegiatan belajar mandiri yang dilakukan oleh mahasiswa dianggap kurang sesuai dengan karakteristik gaya belajarnya dan jika diperoleh lebih dari 2 tanda centang maka dianggap kegiatan belajar mandiri yang telah dilakukan oleh mahasiswa sudah sesuai dengan karakteristik gaya belajarnya.

\section{HASIL DAN PEMBAHASAN}

\section{Kuesioner Gaya belajar}

Sebanyak 69 orang terlibat sebagai responden dalam penelitian ini dan $79 \%$ adalah perempuan. Dari 69 orang mahasiswa, 60 orang $(84 \%)$ memiliki gaya belajar unimodalitas dan hanya 9 orang $(16 \%)$ yang memiliki gaya belajar multimodalitas.
Gambar 1. Distribusi gaya belajar berdasarkan unimodalitas dan multi modalitas

Jika diurut gaya belajar dominan yang dimiliki mahasiswa dari terbanyak sampai sedikit

$$
\text { aimodalitns } \quad \text { SingelMndalitns } \Delta \text { Trimodalitos }
$$

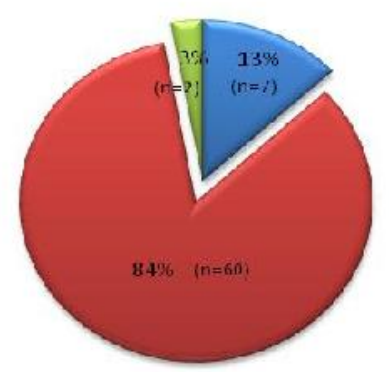

maka diperoleh urutan gaya belajar kinestetik (K) sebanyak 22 orang, gaya belajar aural (A) sebanyak 20 orang, gaya belajar read/write (R) sebanyak 17 orang dan gaya belajar visual (V) sebanyak 1 orang. Gaya belajar multimodalitas yang hanya ada 9 orang tersebar ke gaya belajar VA 1 orang, AR 1orang, AK 3 orang, RK 2 orang, VRK 1 orang dan ARK 1 orang (Gambar 2)

Gambar 2. Distribusi gaya belajar berdasarkan jenis gaya belajar

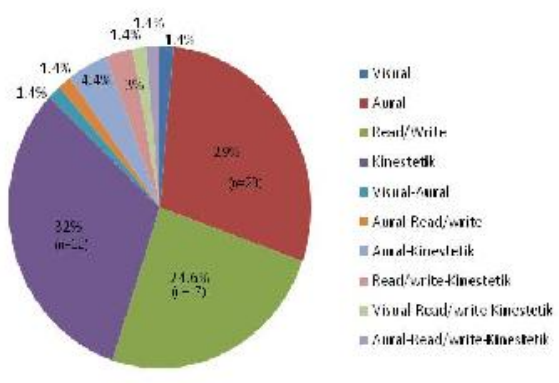

\section{Buku harian belajar mandiri}

Dari tabel 1 tampak bahwa mahasiswa yang memiliki kegiatan belajar mandiri yang sesuai dengan karakteristik gaya belajarnya masih sangat kurang. Mahasiswa yang memiliki kegiatan belajar mandiri kurang sesuai dengan karakteristik gaya belajarnya 2 kali lebih banyak dibanding mahasiswa yang kegiatan belajar mandirinya sesuai dengan karakteristik gaya belajarnya dan yang tidak sesuai kegiatan belajar mandirinya dengan karakteristik gaya belajarnya hanya berbeda 3 orang mahasiswa dari sesuai. 
Untuk gaya belajar multi modalitas diperoleh hasil belajar mandiri sesuai dengan karakteristik gaya belajar adalah sebesar $77.7 \%$ dan yang kurang sesuai adalah sebesar $33.3 \%$. Gaya belajar uni modalitas yang sesuai belajar mandiri dengan karakteristik gaya belajarnya hanya sebesar $10 \%$ dari total mahasiswa yang memiliki gaya belajar uni modalitas, yang kurang sesuai sebesar 58.3\% dan yang tidak sesuai sebesar $8.6 \%$ (tabel 1).

Tabel 1. Distribusi Frekuensi Kesesuaian Belajar Mandiri Dengan KarakteristikGaya Belajar

\begin{tabular}{ccc}
\hline $\begin{array}{c}\text { Kesesuaian } \\
\text { Belajar Mandiri } \\
\text { dengan } \\
\text { Karakteristik } \\
\text { Gaya Belajar }\end{array}$ & Frekuensi & Persentase \\
\hline Sesuai & 13 & $8,7 \%$ \\
\hline Kurang sesuai & 37 & $53,6 \%$ \\
\hline Tidak Sesuai & 19 & $37,7 \%$ \\
\hline TOTAL & 69 & $100 \%$ \\
\hline
\end{tabular}

Gaya belajar kinestetik yang merupakan gaya belajar unimodalitas terbanyak yang dimiliki oleh mahasiswa tahun pertama di FK Unismuh Makassar ternyata pada saat proses belajar mandiri sekitar 59\% dari total gaya belajar kinestetik tidak mengimplementasikan gaya belajarnya pada saat belajar mandiri (lihat tabel 2). Kemungkinan hal ini dimungkinkan karena kegiatan pembelajaran yang berjalan pada blok saat dilakukan penelitian berupa perkuliahan dan praktikum di laboratorium serta penugasan dari tiap-tiap praktikum sehingga cara mencari dan mengambil informasinya tidak sesuai dengan karakteristik dari gaya belajar kinestetik.
Tabel 2. Distribusi Kesesuaian kegiatan Belajar Mandiri dengan Karakteristik Gaya Belajar Berdasarkan Gaya Belajar

\begin{tabular}{|c|c|c|c|}
\hline \multirow[t]{2}{*}{ Gaya Belajar } & \multicolumn{3}{|c|}{$\begin{array}{c}\text { Kesesuaian kegiatan belajar } \\
\text { mandiri dengan } \\
\text { Karakteristik gaya belajar }\end{array}$} \\
\hline & Sesuai & $\begin{array}{c}\text { Kurang } \\
\text { Sesuai }\end{array}$ & $\begin{array}{l}\text { Tidak } \\
\text { Sesuai }\end{array}$ \\
\hline Visual & 0 & 0 & 1 \\
\hline Aural & 3 & 13 & 4 \\
\hline Read/Write & 3 & 13 & 1 \\
\hline Kinestetik & 0 & 9 & 13 \\
\hline Visual-Aural & 1 & 0 & 0 \\
\hline $\begin{array}{l}\text { Aural- } \\
\text { Read/write }\end{array}$ & 1 & 0 & 0 \\
\hline $\begin{array}{l}\text { Aural- } \\
\text { Kinestetik }\end{array}$ & 2 & 1 & 0 \\
\hline $\begin{array}{l}\text { Read/write- } \\
\text { Kinestetik }\end{array}$ & 1 & 1 & 0 \\
\hline $\begin{array}{l}\text { Visual- } \\
\text { Read/write- } \\
\text { Kinestetik }\end{array}$ & 1 & 0 & 0 \\
\hline $\begin{array}{l}\text { Aural- } \\
\text { Read/write- } \\
\text { Kinestetik }\end{array}$ & 1 & 0 & 0 \\
\hline TOTAL & 13 & 37 & 19 \\
\hline
\end{tabular}

\section{Gambaran Gaya Belajar Mahasiswa FK Unismuh Tahun Pertama}

Dari hasil analisis data kuisioner VARK yang dilakukan oleh peneliti, terlihat bahwa pada mahasiswa tahun pertama di Fakulas Kedokteran Universitas Muhammadiyah Makassar gaya belajar yang dominan adalah gaya belajar uni modalitas yaitu sebesar 84\%. Hal ini menunjukkan sebagian besar mahasiswa FK Unismuh lebih menyukai satu bentuk presentasi informasi. Dari beberapa penelitian sebelumnya yang dilakukan pada mahasiswa kedokteran tahun pertama diberbagai negara melaporkan hasil yang tidak sejalan dengan studi ini, dimana mereka memperoleh mayoritas mahasiswa tahun pertama memiliki gaya belajar yang multi modalitas dengan persentase yang bervariasi antara $61-63,9 \% .7,8,9$

Pada preferensi uni modalitas ditemukan bahwa gaya belajar yang paling disukai adalah kinestetik, diikuti oleh aural, read/write dan terakhir visual. Oleh karena itu, strategi pembelajaran aktif seperti bermain peran, simulasi, penggunaan model, debat, dll merupakan hal yang disukai oleh mahasiswa dengan gaya belajar kinestetik dan akan lebih bermanfaat dibandingkan kuliah tradisional. 
Seseorang yang memiliki preferensi gaya belajar kinestetik akan lebih menyukai jika secara fisik terlibat aktif dalam proses pembelajaran, menyususn atau menangani secara fisik materi pembelajaran, menyukai penggunaan komputer, mampu mengingat dengan baik tentang cara kerja sesuatu praktek sekali melakukan praktek dan mempunyai koordinasi motoris yang baik. ${ }^{10}$

Temuan ini sejalan dengan hasil penelitian yang dilakukan oleh Baykan dan Nakar pada mahasiswa kedokteran tahun pertama dari Turki dan mahasiswa tahun pertama di Universitas Sharda, India oleh Kharb dkk. Menurut Lujan dan DiCarlo gaya belajar yang paling disukai mahasiswa kedokteran tahun pertama dari indiana, USA adalah membaca/ menulis. Namun, Nuzhat dkk melaporkan bahwa bentuk pendengaran (Aural) adalah gaya belajar yang paling disukai dikalangan mahasiswa kedokteran tahun pertama di Saudi Arabia. $7,8,9,11$

Pada mahasiswa FK Unismuh didapatkan gaya belajar multimodalitas sebanyak $13 \%$ dari total mahasiswa yang mengikuti penelitian. Semuanya tersebar ke bi modalitas (gabungan 2 modalitas dominan) dan tri modalitas (gabungan 3 modalitas dominan). Temuan ini tidak sejalan dengan dengan penelitian dilakukan oleh Baykan dan $\mathrm{Nakar}^{7}$ pada mahasiswa kedokteran tahun pertama di Turki dan mahasiswa tahun pertama di Universitas Sharda, India oleh Kharb $\mathrm{dkk}^{8}$. Mereka memporeh data statistik dimana preferensi gaya belajar pada mahasiswa tahun pertama yang dominan adalah multimodalitas yaitu sebesar $63.9 \%$ dan $61 \%$.

Mahasiswa dengan preferensi gaya belajar multimodalitas dapat memilih cara mencari dan menerima informasi yang lebih beragam. Mahasiswa ini belajar tidak hanya dengan duduk di kelas mendengarkan kuliah dosen, dan menghafal. Untuk mencapai pembelajaran yang bermakna, para mahasiswa harus berbicara tentang apa yang mereka pelajari, menulis tentang hal tersebut, menghubungkannya dengan pengalaman masa lalu dan pengetahuan dan menerapkannya dalam kehidupan sehari-hari. ${ }^{7}$

Kuliah pasif merupakan metode umum/dominan yang dipergunakan di FK Unismuh Makassar. Semua mahasiswa diasumsikan sebagai pembelajar dengan preferensi audio meskipun dalam penelitian ini hanya $25 \%$ dari mahasiswa yang memiliki preferensi gaya belajar unimodalitas aural. Selain kegiatan kuliah, juga dilakukan kegiatan tutorial, praktikum dan Clinical Skill Training yang dilakukan dilaboratorium dan untuk kegiatan tambahan beberapa mata kuliah blok mengadakan kegiatan observasi di rumah sakit dan puskesmas. Hal ini menjadi penting untuk diperhatikan karena kemampuan siswa untuk mengingat dari apa yang mereka baca hanya sekitar 20\%,30\% dari apa yang mereka dengar, $40 \%$ dari apa yang mereka lihat, 50\% dari apa yang mereka katakana dan $60 \%$ dari apa yang mereka lakukan. Nilai retensi ini akan meningkat hingga $90 \%$ jika informasi mereka peroleh dengan mengatakan, mendengar, melihat dan melakukan. ${ }^{7}$

\section{Aplikasi Gaya Belajar Pada Kegiatan Belajar Mandiri}

Pada penelitian ini diperoleh data bahwa hanya $18.8 \%$ dari total 69 orang mahasiswa yang mengaplikasikan gaya belajar "sesuai" dengan karakteristik gaya belajarnya pada saat belajar mandiri. Hal ini sangat dimungkinkan karena pada saat belajar mandiri, mahasiswa bebas memilih strategi belajar tergantung tujuan-tujuan spesifik yang ingin mereka capai. ${ }^{1}$ Jika dilihat persentase berdasarkan kesesuaian aplikasi gaya belajar (unimodalitas) pada kegiatan belajar mandiri tampak bahwa hanya ada sekitar 10\% yang masuk dalam kriteria "sesuai" dari 60 mahasiswa yang memiliki gaya belajar unimodalitas. Hal ini dapat diartikan bahwa sekitar 80\% mahasiswa dengan gaya belajar unimodalitas ketika belajar mandiri mempergunakan cara belajar yang "kurang" dan "tidak sesuai" dengan karakteristik gaya belajarnya baik itu mempergunakan keterampilan belajar yang sesuai dengan karakteristik gaya belajar uni modalitas lain maupun kombinasi dari beberapa gaya belajar atau multi modalitas.

Jika dibandingkan antara persentase berdasarkan kesesuaian aplikasi gaya belajar unimodalitas dan multimodalitas pada kegiatan belajar mandiri maka tampak perbedaan secara statistik. Mahasiswa dengan preferensi gaya belajar multi modalitas yang mengaplikasikan gaya belajarnya "sesuai" dengan karakteristik gaya belajar tersebut pada saat belajar mandiri mencapai 53\% dari total mahasiswa masuk criteria "sesuai", dan mencapai angka $77.7 \%$ dari total mahasiswa yang memiliki preferensi gaya belajar multi modalitas. Dengan memiliki preferensi gaya belajar multi modalitas, mahasiswa lebih leluasa memilih cara belajar yang sesuai dengan tujuan pembelajarannya. Mahasiswa dapat menggunakan 1, 2 bahkan lebih dari 3 cara memperoleh informasi secara bersamaan dengan menggunakan sebanyak mungkin indra yang dimilikinya. Semakin banyak panca indra yang dipergunakan dalam mencari 
dan memperoleh informasi maka semakin besar resistensi pengetahuan yang dimiliki dan semakin dalam pemahaman terhadap materi tersebut.

Dari beberapa penelitian sebelumnya menemukan bahwa tidak ada korelasi antara preferensi gaya belajar dengan performa hasil belajar yang mungkin membuktikan bahwa tidak ada gaya belajar yang unggul. Belajar dalam gaya yangdisukai hanya membuat pembelajaran mudah dan menyenangkan. ${ }^{12}$

Penelitian gaya belajar ditujukan untuk menemukan lingkungan pembelajaran pelengkap dan untuk mengajarkan gaya yang lebih adaptif kepada pembelajar untuk memperkuat pembelajaran dan motivasi. Mahasiswa yang mengikuti penelitian ini adalah mahasiswa tahun pertama yang berada pada usia masa transisi dari remaja ke dewasa muda. Pada masa tersebut pikiran mereka menjadi lebih abstrak, logis dan idealis.

Gaya juga terkait dengan perkembangan otak dan fungsinya. Perubahan-perubahan yang pesat dan meluas terjadi pada otak remaja memperlihatkan bahwa kita sebaiknya tidak memandang remaja sebagai orang dewasa dalam versi yang lebih kecil. Perkembangan otak merupakan proses sepanjang hidup. Otak terus menerus menambah,menghapus dan mengorganisasi ulang koneksi-koneksi sinaptik dan strukturnya terus berubah. Meskipun aspek perkembangan otak tertentu terjadi lebih cepat pada waktu-waktu tertentu, individu dari segala usia akan diuntungkan dengan adanya lingkungan yang memberikan stimulasi. ${ }^{13}$

Gaya belajar merupakan kebiasaan yang menjadi sebuah kecenderungan yang dipelajari untuk mengulang respon-respon yang pernah dibuat. ${ }^{13}$ Kunci untuk mengubah kebiasaan adalah" menemukan tanda-tanda yang memicu tindakan tersebut dan melatih respon lain terhadap tanda-tanda ini". Gutherine mengidentifikasikan tiga metode untuk mengubah kebiasaan: ambang batas (threshold), keletihan (fatigue), dan respon yang tidak sesuai (incompatible response). ${ }^{13}$

Dalam metode ambang batas (threshold), tanda (stimulus) bagi kebiasaan yang akan diubah (respons yang tidak diinginkan) diberikan dengan level yang lemah sehingga tanda tersebut tidak menghasilkan respon tersebut; levelnya ada dibawah ambang batas level untuk menghasilkan respons. Perlahan-lahan stimulus ini dihadirkan dengan intensitas yang lebih tinggi sampai akhirnya stimulus ini dihadirkan dengan intensitas penuh. Jika stimulus tersebut diberikan dengan intensitas terkuatnya, respon akan berupa perilaku yang harus diubah (kebiasaan). Contohnya, sebagian anak bereaksi terhadap rasa bayam dengan cara menolak memakannya. Untuk mengubah kebiasaan ini, orang tua dapat memberikan bayam dalam gigitan kecil atau mencampurnya dengan makanan yang disukai anak-anak. Seiring dengan waktu, jumlah bayam dalam makanan anak-anak dapat ditingkatkan. Demikian pula halnya dengan preferensi gaya belajar, mahasiswa yang memiliki gaya belajar dominan visual (unimodalitas) akan kesulitan jika diberi tugas membaca dan memahami isi textbook. Kesulitan ini sedikit demi sedikit akan teratasi jika mahasiswa tersebut mulai belajar untuk membaca dan menerjemahkan isi textbook tersebut dengan membuatnya kedalam bentuk flowchart, gambar, simbol maupun underlining/highlithers. Mahasiswa tersebut akan mencapai tujuan pembelajaran dengan memaksimalkan gaya belajar dominan yang dimilikinya dan mulai memadukan gaya belajar dominan tersebut dengan gaya belajar lainnya. Pada akhirnya gaya belajar yang dahulunya tidak dominan perlahan-lahan akan menjadi dominan dikarenakan kebutuhan untuk mencapai tujuan pembelajaran. Pengalaman dari belajar ini akan menciptakan suatu perubahan pada (1) keterampilan mereka, (2) perilaku (3) tingkat pengetahuan, atau bahkan(4) sikap mereka terhadap suatu hal. ${ }^{10}$

Selama masa pendidikan, peranan Dosen Pembimbing Akademik (DPA) dalam memberikan bimbingan dan pendampingan sangat besar, salah satunya terkait gaya belajar, strategi belajar, dan motivasi dalam mencapai tujuan pembelajaran oleh karena itu dibutuhkan komitmen dari DPA dan institusi pendidikan untuk membantu mahasiswa dalam menjalani pendidikannya. Selain DPA, institusi juga memegang peranan penting dalam keberhasilan proses belajar mahasiswa. Kebijakan akan pelaksanaan kegiatan belajar-mengajar, pengadaan sarana dan prasarana pembelajaran, serta penciptaan suasana belajar yang kondusif dengan kondisi mahasiswa tak lepas dari peranan Institusi.

Studi yang dilakukan oleh Bonwel \& Eison dan Lujan \& Dicarlo memperlihatkan bahwa siswa dapat belajar lebih baik dengan menggunakan strategi pembelajaran aktif., 814 Strategi pembelajaran aktif akan mendorong siswa untuk dapat berfikir menggunakan penalaran dan meningkatkan pengetahuan problem solving dan kemampuan/ keterampilan pengambilan keputusan. Dalam kelas besar, 
strategi pembelajaran aktif juga dapat diterapkan. Diskusi kelas, latihan pembelajaran kooperatif, bermain peran, simulasi, model perdebatan dan permainan strategi. Dengan model pembiasaan seperti ini, strategi pembelajaran tersebut dapat diadopsi oleh mahasiswa sesuai karakteristik gaya belajarnya dan sedikit demi sedikit dapat mengembangkan preferensi gaya belajarnya dari unimodalitas menuju ke multimodalitas.

\section{SIMPULAN}

Penelitian ini menunjukkan bahwa gaya belajar dominan mahasiswa tahun pertama di FK Unismuh Makassar adalah gaya belajar kinestetik (unimodalitas) diikuti oleh aural, read/write dan terakhir visual. Mahasiswa yang memiliki gaya belajar multimodalitas hanya sekitar 13\% dari 69 orang total subjek penelitian.

Saat belajar mandiri, mahasiswa yang memiliki gaya belajar unimodalitas kurang mengimplementasikan gaya belajar "sesuai" karakteristik gaya belajar tersebut berbeda dengan hasil statistik yang diperoleh untuk gaya belajar multimodalitas yang sebagian besar mengimplementasikan gaya belajar "sesuai" dengan karakteristik gaya belajarnya. Mahasiswa yang memiliki gaya belajar multimodalitas lebih leluasa memilih cara belajar yang sesuai kebutuhan atau tujuan pembelajaran dibandingkan yang unimodalitas.

Tidak ada gaya belajar yang unggul. Belajar dalam gaya yang disukai hanya membuat pembelajaran mudah dan menyenangkan. Penelitian akan gaya belajar hanya ditujukan untuk menemukan lingkungan pembelajaran pelengkap dan untuk mengajarkan gaya yang lebih adaptif kepada pembelajar untuk memperkuat pembelajaran dan motivasi.

\section{DAFTAR PUSTAKA}

1. Ormrod JE. Human Learning, $6^{\text {th }}$ Ed. USA: Pearson Prentice Hall. 2012.

2. Entwistle N. Improving teaching through research on student learning. In J. Forest ed. UniversityTeaching. International perspectives. New York and London: Garland Publishing, Inc; 1998. 74 - 112.

3. Cox K. Knowledge Which Cannot Used is Useless. Medical teacher, 1998. 9(2), pp. 145154.

4. Reid GLearning Style and Inclusion. Edinburgh, Scotland: Paul Chapman Publishing. 2005.
5. Jones BF, Palincsar AS, Ogle DS, and Carr E G. Strategic teaching and learning: Cognitive instruction in the content areas. Alexandria, VA: Association for Supervision and Curriculum Development. 1987

6. Flemming N. VARK: A Guide to Learning Style. http// http://www.varklearn.com/english/page.asp? $\mathrm{p}=$ questionnai re. [Accessed 19 Februari 2010].

7. Baykan Z, Nacar M, Learning Styles of First Year Medical Student Attending Erciyes University in Kayscri, Turkey. Adv Physiol Educ; 2007; (31):158-60.

8. Kharb P, Samanta P.P, Jindal M, and Singh V., The Learning Style and The Preferred Teaching-Learning Strategies of First Year Medical Students, Journal of Clinical and Diagnostic Reasearch, June Vol-7 (6): 10891092.

9. Lujan H. L and Dicarlo S.E, First-Year Medical Student Prefer Multiple Learning Styles. Adv Physiol Educ. 2006; 30(1):1316.

10. Russell, SS. An Overview of Adult-learning Process. Urologic Nursing 2006; 26(5):349353,570 .

11. Nuzhat A, Salem RO, Mohammes SA, Nasir Al-Hamdan. Learning style preferences of medical students: a singleinstitute experience from Saudi Arabia. Int J Med Edu, 2011; (2):70-73.

12. Shenoy N, Shenoy A, and P.U. Ratnakar. The Perceptual Preference in Learning Among Dental Students in Clinical Subjects, Journal of Clinical and Diagnostic Reasearch, 2013 Aug Vol-7 (8): 1683-1685.

13. Shunck,D.H. Teori Pembelajaran: Perspektif Pendidikan, ed 6. Yogyakarta: Pustaka Pelajar. 2012

14. Bonwell CC, Eison JA. Active Learning: Creating Excitement in the Classroom.Washington, DC: George Washington Univ. 1991 